\title{
EMPIRICAL MODELS FOR THE EVALUATION OF GLOBAL SOLAR RADIATION IN THE DIFFERENT SITES OF NEPAL
}

\author{
B. P. Pant, K. N. Poudyal, B. Acharya, B. Budha
}

Journal of Nepal Physical Society

Volume 5, Issue 1, October 2019

ISSN : 2392-473X

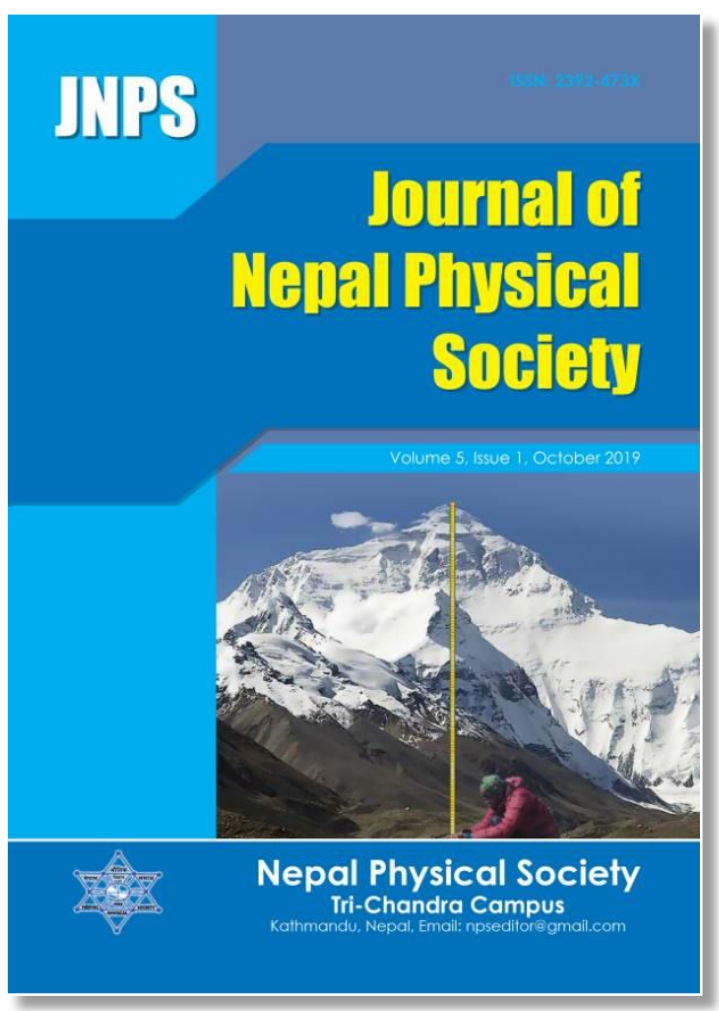

Editors:

Dr. Vinaya Kumar Jha

Dr. Binod Adhikari

Dr. Kapil Adhikari

JNPS, 5 (1), 67-73 (2019)

\section{Nenal Physical Socioty}




\title{
EMPIRICAL MODELS FOR THE EVALUATION OF GLOBAL SOLAR RADIATION IN THE DIFFERENT SITES OF NEPAL
}

\author{
B. P. Pant ${ }^{1, *}$, K. N. Poudyal ${ }^{2}$, B. Acharya ${ }^{3}$, B. Budha ${ }^{3}$ \\ ${ }^{I}$ Department of Physics, St. Xavier's College, Maitighar, Kathmandu, Nepal \\ ${ }^{2}$ Central Department of Physics, Tribhuvan University, Kathmandu, Nepal \\ ${ }^{3}$ St.Xavier's College Maitighar, Kathmandu, Nepal \\ "Corresponding Email: birendra.pant@sxc.edu.np/ptbiren@gmail.com
}

\begin{abstract}
To operate many phenomenon's on the earth surface such as physical, chemical and biological process solar radiation plays vital role. A common practice is to estimate average daily global solar radiation (GSR) using appropriate empirical models for the areas lacking the actual measured values. In this context several single and multiple meteorological parameters were selected to estimate the GSR for Jumla, Nepalgunj and Kathmandu. In order to validate the selected models various statistical test were employed. The selected models were compared on the basis of statistical errors. In the statistical analysis the value of root mean square error (RMSE) and coefficient o determination $\mathrm{R}^{2}$ is found to 0.15.0.23, 0.26 and $0.98,0.96,0.96$ respectively for Jumla, Nepalgunj and Kathmandu in Samuel model. These values were comparatively better than other models. It is concluded that Samuel model (order three) is the best among the used models. The established result uncover that there is a good possibility of solar energy as a alternative energy source in Nepal.
\end{abstract}

Keywords: Empirical models, Global solar radiation, Regression constants, statistical error, Sunshine hour.

\section{BACKGROUND}

It is essential to have knowledge on global solar radiation of the study site in order to design and operate the solar energy devices. Solar engineers, agriculturists and hydrologists use the solar radiation data for various purposes such as soar heating, cooking, drying and interior illumination of buildings $[1,2]$. Since it has a huge economic uses as a renewable energy, lots of studies have been done due to its importance in contributing energy for Earth's climate system. Several factors do play role in quantifying the solar radiation on earth's surface. Among them, the climatic condition and geography of the site affect the amount of the solar radiation received by earth's surface. The data or information obtained from the study of a particular site not only useful for the site but also forms a basis for estimating the global solar radiation for the wider world. So, the extraction of global solar radiation data requires the knowledge of the radiation data of various sites and for that proper worldwide marketing, the designers and manufacturers of solar equipment will be needed to know the average GSR available in different and specific regions [3]. Since the GSR depends upon various parameters, so for a particular given sites, a proper solar radiation model can be useful for the study of global solar radiation. The availability of a solar radiation model, for the region, is very useful in estimating the amount of power that could be generated from a particular solar energy system [2]. For the application of solar energy in the context of Nepal, it is compulsory to develop data base in order to use it in active and passive energy form which could be a giant step for development of many sectors like communication, tourism, education, industry, community health and scientific agriculture. One of the practical possibilities of renewable energy for the electrification of rural area is photovoltaic [26].

The genuine and reliable information regarding the solar radiation for the particular site can be applied in various fields like hydrology, modern agriculture, solar active energy, solar passive energy, water storage reservoir, irrigation system and climate change. Further, specific understanding on GSR is 
required in order to design solar energy system ([26]. Although we are aware of the importance of solar irradiance data, very few number of measuring equipment are available and due to lack of regular maintenance and calibrations of sensors, most of the stations have missing data $[4,5]$. In addition, for the developing countries like Nepal, due to the cost and need of regular maintenance, calibrations of measuring equipment, solar radiations measurements are not accessible [6]. So, mostly we have to rely on several models/methods to estimate the solar radiation based on the easily available meteorological parameters.

The geographical location of Nepal is in favorable latitude and receives sufficient and adequate amount of solar radiation throughout the country. From the various research works, the variation of average global solar radiation varies about 3.6- 6.2 $\mathrm{kWh} / \mathrm{m}^{2} /$ day and sun shines about 300 days in a year. The national average sunshine hours and solar energy are $6.8 /$ day and $4.7 \mathrm{kWh} / \mathrm{m}^{2} /$ day respectively [7].

Several types of empirical models can be used to estimate the daily average solar radiation as a function of readily measured climatic data. On the basis of different models many research paper have been published for the determination of monthly averaged global solar radiation and some of regression coefficients/constants obtained from these models are globally applicable, while others are place dependent [5]. Several studied model shown that the best performing models are those where sunshine duration are used and those utilize cloudiness and temperature are secondary model on basis of performance $[8,9]$.

The prime focus of this investigation was to validate the performance of six temperatures and sunshine duration based empirical models.

\begin{tabular}{|l} 
Nomenclature: \\
$\mathrm{H}_{\mathrm{g}} \quad \begin{array}{l}\text { monthly average daily global solar } \\
\text { radiation on the horizontal surface of } \\
\text { selected location }\left(\mathrm{MJm}^{-2} \text { day }^{-1}\right)\end{array}$ \\
$\mathrm{H}_{\mathrm{o}} \quad$\begin{tabular}{l} 
monthly average daily extraterrestrial \\
\hline
\end{tabular}
\end{tabular}

\begin{tabular}{|c|c|}
\hline & $\begin{array}{l}\text { global solar radiation for the selected } \\
\text { location }\left(\mathrm{MJm}^{-2} \mathrm{day}^{-1}\right)\end{array}$ \\
\hline $\mathrm{T}_{\max }$ & $\begin{array}{l}\text { monthly average daily maximum } \\
\text { temperature }\left({ }^{\circ} \mathrm{C}\right)\end{array}$ \\
\hline $\mathrm{T}_{\min }$ & $\begin{array}{l}\text { monthly average daily minimum } \\
\text { temperature }\left({ }^{\circ} \mathrm{C}\right)\end{array}$ \\
\hline s & $\begin{array}{l}\text { monthly average daily hours of bright } \\
\text { sunshine (h) }\end{array}$ \\
\hline$S$ & monthly average day length (h) \\
\hline $\mathrm{I}_{\mathrm{sc}}$ & solar constant $\left(=1367 \mathrm{Wm}^{-2}\right)$ \\
\hline $\mathrm{n}$ & $\begin{array}{l}\text { number of days starting from first } \\
\text { January }\end{array}$ \\
\hline $\mathrm{Z}$ & altitude of site (m) \\
\hline RMSE & root- mean square error $\left(\mathrm{MJ} / \mathrm{m}^{2} /\right.$ day $)$ \\
\hline MBE & mean bias error $\left(\mathrm{MJ} / \mathrm{m}^{2} /\right.$ day $)$ \\
\hline MPE & mean percentage error \\
\hline MABE & mean absolute bias error $\left(\mathrm{MJ} / \mathrm{m}^{2} /\right.$ day $)$ \\
\hline MAPE & mean absolute percentage error \\
\hline $\mathrm{SD}$ & standard deviation $\left(\mathrm{MJ} / \mathrm{m}^{2} /\right.$ day $)$ \\
\hline GSR & Global solar radiation \\
\hline$a-d$ & regression coefficients \\
\hline \multicolumn{2}{|c|}{ Greek letters } \\
\hline$\partial$ & solar declination angle (deg) \\
\hline$\omega$ & $\begin{array}{l}\text { mean sunshine hour angle for the given } \\
\text { month (deg) }\end{array}$ \\
\hline$\phi$ & latitude of the site (deg) \\
\hline
\end{tabular}

\section{Description of sites and approach of data analysis}

Due to the geographical location of Nepal in world map, it receives moderate solar radiation. In order to get reliable and better analytic performance of six empirical models of study sites of different geographical locations are introduced. Variation of altitude for the three regions namely Midwester and Central which contains three selected sites ranges from $150 \mathrm{~m}$ (Nepalgunj) to $2347 \mathrm{~m}$ (Jumla) from mean sea level and this study is focused on these sites. The geographical location of selected site is specified in table 1 .

Table 1: Geographical locations of the studied sites.

\begin{tabular}{llcccc}
\hline \multicolumn{1}{c}{ Region } & \multicolumn{1}{c}{ Site } & Latitude $\left({ }^{\mathbf{0}} \mathbf{N}\right)$ & Longitude $\left({ }^{\mathbf{0}} \mathbf{E}\right)$ & Elevation $(\mathbf{m})$ & Year \\
\hline Mid-western & Jumla & 29.27 & 82.19 & 2347 & 2011 \\
Mid-western & Nepalgunj & 28.05 & 81.61 & 165 & 2014 \\
Central & Kathmandu & 27.69 & 85.35 & 1338 & 2011 \\
\hline
\end{tabular}




\section{Selected models for the determination of GSR}

Firstly Angstrom [10] and Prescott [11] formulated the relation for the determination of global solar radiation and various models based on the commonly available meteorological parameter are employed in the past for the same reason. In our study six different empirical models are applied in order to study the GSR for the study sites. Out of these six empirical models two are based on the temperature and other four models are based on the sunshine hour as input parameter.

3.1. Estimation of extraterrestrial solar radiation (Ho): The monthly average daily extraterrestrial radiation on a horizontal surface of the studied location can be computed by using following relation [12]

$$
\mathrm{H}_{\mathrm{o}}=\frac{24}{\pi} \mathrm{I}_{\mathrm{sc}}\left[1+0.033 \operatorname{Cos} \frac{360 \mathrm{n}}{365}\right]\left[\operatorname{Cos} \phi \operatorname{Cos} \partial \operatorname{Sin} \omega+\frac{\pi}{180} \omega \operatorname{Sin} \Phi \operatorname{Sin} \partial\right]
$$

Where $\mathrm{I}_{\mathrm{sc}}$ is solar constant $\left(=1367 \mathrm{Wm}^{-2}\right)$

The solar declination angle $(\partial)$ and the mean sunshine hour $(\omega)$ can be enumerated by using the equations (2) and (3) respectively [1, 12]

$\delta=23.45 \operatorname{Sin}\left[\frac{360(284+\mathrm{n})}{365}\right]$

Where $\mathrm{n}$ is number of days starting from first January
$\omega=\operatorname{Cos}^{-1}(-\tan \phi \tan \partial)$

$\phi$ is latitude of the site

The maximum feasible sunshine length for a given month can be obtained by employing the given equation $[1,12]$.

$\mathrm{S}=\frac{2}{15} \omega$

Table 2: List of models used for the determination of global solar radiation.

\begin{tabular}{|c|c|c|c|}
\hline Model & Symbol & Parameter required & Relation \\
\hline $\begin{array}{l}\text { Hargeaves and } \\
\text { Samani [13] }\end{array}$ & M1 & Ho, Tmax, Tmin & $\frac{\mathrm{H}_{\mathrm{g}}}{\mathrm{H}_{\mathrm{o}}}=\mathrm{a}\left(\mathrm{T}_{\max }-\mathrm{T}_{\min }\right)^{0.5}$ \\
\hline $\begin{array}{l}\text { Annandale et al. } \\
\text { [14] }\end{array}$ & M2 & Ho, Tmax, Tmin, Z & $\frac{\mathrm{H}_{\mathrm{g}}}{\mathrm{H}_{\mathrm{o}}}=\left[\mathrm{a}\left(1+2.7 \mathrm{X} 10^{-5} \mathrm{Z}\right)\left(\mathrm{T}_{\max }-\mathrm{T}_{\min }\right)^{0.5}\right]$ \\
\hline $\begin{array}{l}\text { Ampratwum and } \\
\text { Dorvlo model [15] }\end{array}$ & M3 & Ho, s,S & $\frac{\mathrm{H}_{\mathrm{g}}}{\mathrm{H}_{\mathrm{o}}}=\mathrm{a}+\mathrm{b} \log \left(\frac{\mathrm{s}}{\mathrm{S}}\right)$ \\
\hline Newland model [16] & M4 & Ho, s,S & $\frac{\mathrm{H}_{\mathrm{g}}}{\mathrm{H}_{\mathrm{o}}}=\mathrm{a}+\mathrm{b}\left(\frac{\mathrm{s}}{\mathrm{S}}\right)+\mathrm{clog}\left(\frac{\mathrm{s}}{\mathrm{S}}\right)$ \\
\hline $\begin{array}{l}\text { Akinoglu and Ecevit } \\
\text { model [17] }\end{array}$ & M5 & Ho, s,S & $\frac{\mathrm{H}_{\mathrm{g}}}{\mathrm{H}_{\mathrm{o}}}=\mathrm{a}+\mathrm{b}\left(\frac{\mathrm{s}}{\mathrm{S}}\right)+\mathrm{c}\left(\frac{\mathrm{s}}{\mathrm{S}}\right)^{2}$ \\
\hline Samuel model [18] & M6 & Ho, s,S & $\frac{\mathrm{H}_{\mathrm{g}}}{\mathrm{H}_{\mathrm{g}}}=\mathrm{a}+\mathrm{b}\left(\frac{\mathrm{s}}{\mathrm{S}}\right)+\mathrm{c}\left(\frac{\mathrm{s}}{\mathrm{S}}\right)^{2}+\mathrm{d}\left(\frac{\mathrm{s}}{\mathrm{S}}\right)^{3}$ \\
\hline
\end{tabular}

\section{Methodology, Comparison techniques of used} model and their validation

The value of global solar radiation on the horizontal site of the studied location was measured by CMP6 pyranometer and estimated value of GSR obtained from the implementation of models M1 to M6 for three different sites were compared with the ground measured data. In order to validate the performance of individual used model various statistical indicator were used. The statistical parameter includes; mean percentage error (MPE), mean absolute percentage error (MAPE), root mean square error (RMSE), mean absolute bias error (MABE), mean bias error (MBE), standard deviation (SD) and coefficient of 
determination $\left(\mathrm{R}^{2}\right)$. To compare solar radiation models performance, these statistical tests are generally implemented and provide reasonable norms for the validation of model $[19,20]$ MPE, MAPE, MABE, MBE, RMSE, SD, $R^{2}$ and $r$ are interpreted as below $[1,2,13,20]$

MPE $=\frac{1}{N} \sum_{i=1}^{N}\left(\frac{H_{c}-H_{m}}{H_{m}}\right) X 100$

MAPE $=\frac{1}{N} \sum_{i=1}^{N}\left|\frac{\mathrm{H}_{\mathrm{c}}-\mathrm{H}_{\mathrm{m}}}{\mathrm{H}_{\mathrm{m}}}\right| \mathrm{X} 100 \%$

$\mathrm{MABE}=\frac{1}{\mathrm{~N}} \sum_{\mathrm{i}=1}^{\mathrm{N}}\left|\mathrm{H}_{\mathrm{c}}-\mathrm{H}_{\mathrm{m}}\right| \mathrm{MJ} / \mathrm{m}^{2} /$ day

$\mathrm{MBE}=\frac{1}{\mathrm{~N}} \sum_{\mathrm{i}=1}^{\mathrm{N}}\left(\mathrm{H}_{\mathrm{c}}-\mathrm{H}_{\mathrm{m}}\right) \mathrm{MJ} / \mathrm{m}^{2} /$ day

$\operatorname{RMSE}=\left[\frac{1}{\mathrm{~N}} \sum_{\mathrm{i}=1}^{\mathrm{N}}\left(\mathrm{H}_{\mathrm{c}}-\mathrm{H}_{\mathrm{m}}\right)^{2}\right]^{\frac{1}{2}} \quad \mathrm{MJ} / \mathrm{m}^{2} /$ day $\cdots(9)$
$S D=\sqrt{\frac{\sum_{i=1}^{N}\left(H_{i}-\bar{H}\right)^{2}}{N}} \mathrm{MJ} / \mathrm{m}^{2} /$ day

$\mathrm{R}^{2}=\frac{\left[\sum_{\mathrm{i}=1}^{\mathrm{N}}\left(\mathrm{H}_{\mathrm{c}}-\mathrm{H}_{\mathrm{c}, \mathrm{avg}}\right)\left(\mathrm{H}_{\mathrm{m}}-\mathrm{H}_{\mathrm{m}, \mathrm{avg}}\right)\right]^{2}}{\sum_{\mathrm{i}-1}^{\mathrm{N}}\left(\mathrm{H}_{\mathrm{c}}-\mathrm{H}_{\mathrm{c}, \mathrm{avg}}\right)^{2}\left(\sum_{\mathrm{i}=1}^{\mathrm{N}} \mathrm{H}_{\mathrm{m}}-\mathrm{H}_{\mathrm{m}, \mathrm{avg}}\right)^{2}}$

Where $\mathrm{H}_{\mathrm{m}}$ is the measured value, $\mathrm{H}_{\mathrm{c}}$ is the calculated value of solar radiation and $\mathrm{n}$ is the number of comparisons, $\mathrm{H}_{\mathrm{m}, \mathrm{avg}}$ is average of measured value of solar radiation, $\mathrm{H}_{\mathrm{c}, \mathrm{avg}}$ is the average of calculated value of solar radiation, $\bar{H}$ is mean value of radiation, The units of radiation are $\mathrm{MJ} / \mathrm{m}^{2} /$ day.

The statistical result of various single-multiple parameters models used in the study is mentioned in the table 3 .

Table 3: Statistical indicators for empirical models employed in the research for three different sites of Nepal.

\begin{tabular}{cccccccc}
\hline Location/ Model & $\begin{array}{c}\text { MPE } \\
(\%)\end{array}$ & $\begin{array}{c}\text { MAPE } \\
(\%)\end{array}$ & $\begin{array}{c}\text { MBE } \\
\left(\mathbf{M J} / \mathbf{m}^{2} / \mathbf{d a y}\right)\end{array}$ & $\begin{array}{c}\text { MABE } \\
\left(\mathbf{M J} / \mathbf{m}^{2} / \mathbf{d a y}\right)\end{array}$ & $\begin{array}{c}\mathbf{R M S E} \\
\left(\mathbf{M J} / \mathbf{m}^{2} / \mathbf{d a y}\right)\end{array}$ & $\begin{array}{c}\text { SD } \\
\left(\mathbf{M J} / \mathbf{m}^{2} / \mathbf{d a y}\right)\end{array}$ & $\mathbf{R}^{\mathbf{2}}$ \\
\hline Jumla & & & & & & & \\
\\
M1 & 0.95 & 4.34 & -0.25 & 0.89 & 0.32 & 3.43 & 0.91 \\
M2 & 0.95 & 4.34 & 0.24 & 0.89 & 0.32 & 3.43 & 0.91 \\
M3 & 0.10 & 2.73 & 0.01 & 0.50 & 0.18 & 3.51 & 0.97 \\
M4 & 0.15 & 2.91 & -0.06 & 0.56 & 0.17 & 3.36 & 0.97 \\
M5 & 0.06 & 2.56 & -0.01 & 0.48 & 0.16 & 3.44 & 0.97 \\
M6 & 0.97 & 2.73 & -0.21 & 0.53 & 0.15 & 3.43 & 0.98
\end{tabular}

Nepalgunj

M1

M2

M3

M4

M5

M6

Kathmandu

M1

M2

$-3.35$

0.30

9.11

0.14

0.14

0.21

$-0.63$

6.59

0.22

6.68

0.22

$-0.63$

6.69

0.22

6.74

11.44

0.38

0.38

0.12

0.11
$-0.63 \quad 6.92$

6.66

M5

M6
0.11

0.12

6.17

$-0.58$

$-0.62$

6.67
1.57

1.57

0.54

0.54

0.37

0.37

0.37

0.23

1.54

1.54

0.97

0.93

0.94

0.90
0.54

0.54

0.34

0.33

0.33

0.26
4.67

4.67

0.89

0.89

4.08

0.92

4.13

0.93

4.13

0.93

4.13

0.96

$2.75 \quad 0.59$

$2.75 \quad 0.59$

$3.06 \quad 0.86$

$2.99 \quad 0.86$

$3.02 \quad 0.86$

$3.10 \quad 0.96$ 


\section{RESULTS AND DISCUSSION}

Easily available meteorological parameters based six on empirical models are used in this study for the estimation of global solar radiation at three different sites of Nepal. The monthly averaged daily global solar radiation estimated by employing above models three studied sites were compared with corresponding value of measured radiation. To analyze the soundness of used models we perform diverse statistical test. The statistical indices employed in all applied models are MPE, MAPE, MBE, MABE, RMSE, SD and $\mathrm{R}^{2}$. The outcomes of these statistical indicators are mentioned in table 3 . Also, empirical coefficients obtained by data analysis regression technique for all implemented models are condensed in table 4.

Table 4: Empirical coefficients for the selected model.

\begin{tabular}{lllll}
\hline Location & a & b & c & d \\
\hline Jumla & & & & \\
M1 & 0.16 & & & \\
M2 & 0.15 & & & \\
M3 & 0.73 & 0.33 & & \\
M4 & 0.50 & 0.25 & 0.03 &
\end{tabular}
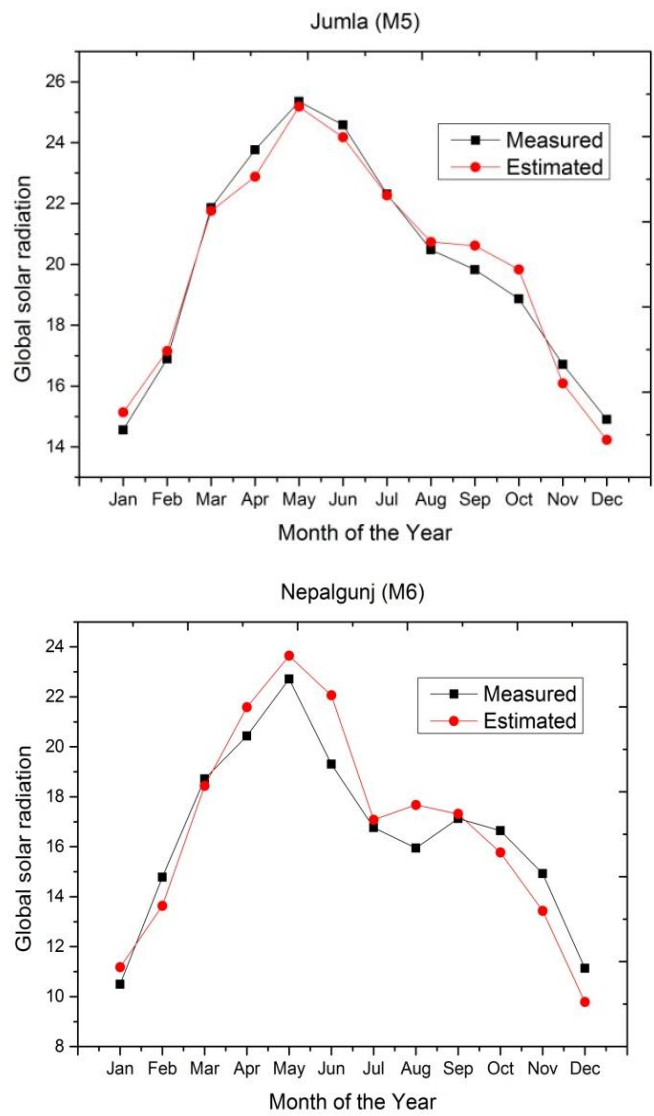

M5

$0.45 \quad 0.22$

0.11

M6

0.27

1.34

2.10

Nepalgunj

M1

0.14

M2

0.14

M3

$0.63 \quad 0.52$

M4

$0.35 \quad 0.31$

M5

$\begin{array}{lll}0.27 & 0.43 & 0.03\end{array}$

M6

0.14

2.62

3.82

Kathmandu

M1

0.13

M2

0.13

M3

$0.68 \quad 0.65$

M4

0.38

$0.38 \quad 0.30$

M5

0.04

$1.13 \quad 0.50$

M6

0.42

1.2

3.02

5.15

\section{Study area and selected models}

The sunshine hour based model perform well in estimating GSR (Table 3 ) for the studied sites. The best performance of model for the given site is represented in fig 1 .
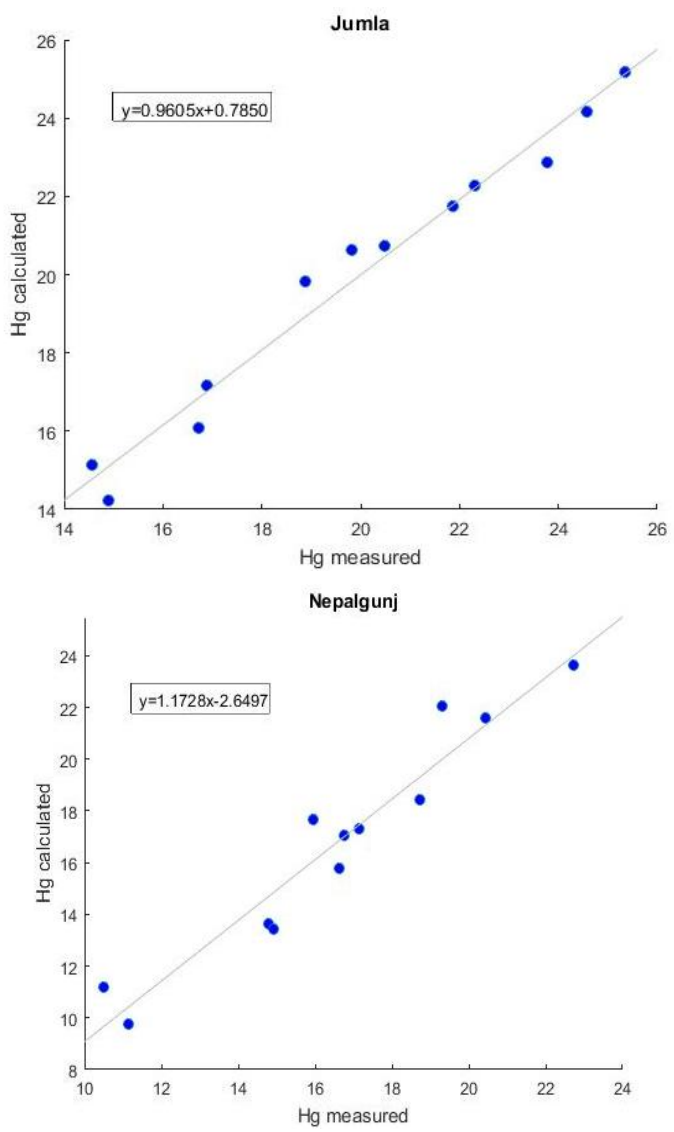

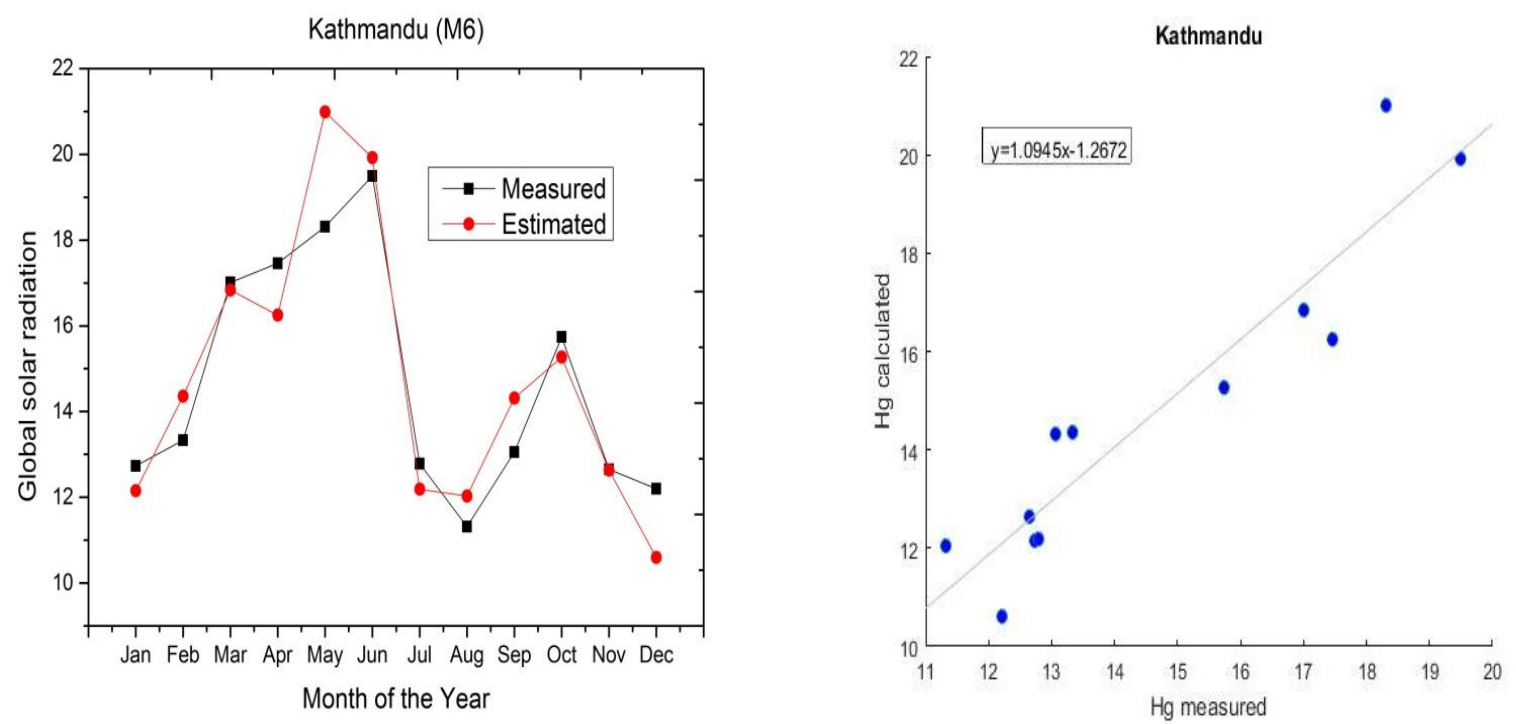

Fig. 1: Graph showing the relation between measured and estimated value of $G S R\left(M J / \mathrm{m}^{2} /\right.$ day) and scatter plot for the selected model for the given location.

In the study for the determination of global solar radiation, we have taken various single-multiple meteorological parameter models. Among those model, Annandale et al. (M2) is the multiple parameter model based on the model M1 in addition with the site altitude and rest of the models M1, M3-M6 are parameterized by single meteorological parameter temperature $(\mathrm{T})$ and sunshine duration (s) respectively. From the statistical indicators (table 3) it has been found that Samuel model performs best among the used models indicating least value of RMSE and highest value of coefficient of determination.

The duration of radiation and intensity also play the vital role for the radiation received by the particular location. Above graph shows the value of global solar radiation received is maximum in the month of April and May it is mainly due to less cloud, slow wind, less rainfall and less solar zenith angle. However, the normal trend deviates for the months of June, July and August for all the studied sites due to the fact that they are rainy reasons for the country and maximum rainfall of the year occurs in these months. In the summer or monsoon season the average rainfall is about 70 to 90 percent of whole year and remaining month's remains almost dry [22]. In rainy season sky over the particular place is covered by cloud and this reduces the solar radiation reaching to the ground surface.

The meteorological factors such as rainfall, sunshine duration and temperature not only effect the global solar radiation but there are many other factors which effect on it. Astronomical factors such as solar declination angle and hour angle varies over the year and so the amount of radiation. Geometrical factor such as solar zenith angle also effect the radiation received by the particular location. In addition to that, physical factors such as scattering of air molecules, water vapor content, scattering of dust, cold wave and location level atmospheric pollution has effect on radiation acquired by particular location.

\section{CONCLUSION}

The validation of different models is evaluated on the basis of various statistical parameters such as; MPE, MAPE, MABE, MBE, RMSE, SD and $\mathrm{R}^{2}$. Based on the statistical interpretation, the obtained result reveals that sunshine duration related Samuel model shows better correlation with the measured result for the studied sites. In this study, the range of monthly averaged daily values of minimum and maximum global solar radiation is $14.56-25.35$, $10.49-22.71,11.31-19.49 \mathrm{MJ} / \mathrm{m}^{2} /$ day respectively for jumla, Nepalgunj and Kathmandu.

\section{ACKNOWLEDGEMENT}

The authors are grateful to the department of Hydrology and Meteorology (DHM), Government of Nepal for the meteorological data.

\section{REFERENCES}

[1] Pant Birendra P. et al. Evaluation of global solar radiation with single and multiple parameter models in midwestern region Jumla, Nepal, 
Research Journal of Physical Science., 5 (8), 1-6, (2017).

[2] M. Jamil Ahmad, G.N. Tiwari. International Journal of Energy and Environment, 1 (3), 513532 (2010).

[3] Louis E. AKPABIO et al. Relationship between Global Solar Radiation and Sunshine Duration for Onne, Nigeria Turk J Phys (27), 161-167 (2003).

[4] Hunt LA, Kuchar L, Swanton CJ. Estimation of solar radiation for use in crop modeling. Agric For Meteorol; 91; 293-300 (1998).

[5] Iziomon MG, Mayer H. Assessment of some global solar radiation parameterizations. J Atmos Solar Terr Phys 64: 1631-43 (2002).

[6] K.N. Poudyal. "Estimation of Global Solar Radiation Potential in Nepal", Ph.D. Dissertation IOE, TU (2015).

[7] WECS. Water and Energy Commission Secretariat, Energy Sector Synopsis Report Nepal (2010).

[8] Bakirci K. Models of solar radiation with hours of bright sunshine: a review Renew Sustain Energy Rev.13: 2580-8 (2009).

[9] Li M, Fan L, Liu H, Fuo P,Wu W. A general model for estimation of daily global solar radiation using air temperature and site geographic parameters in Southwest China. J Atmos Solar Terr Phy;92: 145-50 (2013).

[10] Angstrom A. Solar and terrestrial radiation, Quart. J. Roy., Meteo. Soc., 50, 121-125 (1994).

[11] Prescott J.A. Evaporation from a water surface in relation to solar radiation, Tran, Roy, So. Aust., 64, 114-118 (1940).

[12] Duffie J.A., Beckman W.A. Solar engineering of thermal processes. New York, Wiley (1991).
[13] Victor H. Quej et al. Empirical models for the estimating daily global solar radiation in Yucatan Peninsula, Mexico Energy conservation and management 110 448-456 (2016).

[14] Annandale J, Jovanovic N, Benade N, Allean R. Soft ware for missing data error analysis of Penman-Monteith reference evapotranspiration. Irring, Sci 21:57-67 (2002)

[15] Ampratwum DB, Dorvlo ASS. Estimation of solar radiation from the number of sunshine hours. Applied Energy 63:161-7 (1999).

[16] Newland FJ. A study of solar radiation models for the coastal region of South China. Solar Energy; 31:227-35 (1988).

[17] Rietveld M.R.A. newmethod for estimating the regression coefficientsin the formula relating solar radiation to sunshine. Agricultural Meteorology;19:243-52 (1978).

[18] Samuel TDMA. Estimation of global radiation for Sri Lanka. Solar Energy; 47:333-7 (1991).

[19] Emad Ali Ahmed. Journal of Multidisciplinary Engineering Science and Technology (JMEST) 2 (7) (2015).

[20] Teke A et al. Evaluation and performance comparison of different models for the estimation of solar radiation. Renew Sustain Energy Rev; 50;1097-107 (2015).

[21] Besharat F. et al. Empirical models for estimating global solar radiation: a review and case study. Renewable and Sustainable Energy Reviews, 21 798-821 (2013).

[22] Resham Bahadur Thapa et al. Impact of climate Change on Wheat Production in Nepal, Asian Journal of Agriculture Extension, Economics \& Sociology 9 (2): 1-14 (2016). 